\title{
PATRÕES E CLIENTES OU REDISTRIBUIÇÃO ENTRE IGUAIS? UMA REVISÃO SOBRE CLIENTELISMO POLÍTICO E SUAS TRANSPOSIÇÕES CONTEXTUAIS*
}

Laura Colabella

\section{Introdução}

Alguns dias após a eleição de Cristina Fernández como presidente da Argentina, em novembro de 2007, visitei Rubén, ${ }^{1}$ um vereador peronista do município de La Matanza, localizado a oeste da Grande Buenos Aires. Meu contato com ele tinha se iniciado no princípio de 2005, quando cheguei a Santa Rita, a villa ${ }^{2}$ na qual residia com sua mulher, seus dez filhos e três netos. Eles foram meus anfitriões por extensos sete meses, período em que desenvolvi meu trabalho de campo naquele bairro, e que coincidiu com a campanha legislativa de outubro de 2005, na qual Rubén era candidato. A oferta para que ocupasse um cargo eletivo havia sido feita por Balestrini, seu chefe político e prefeito do município, candidato a deputado federal. Cristina Fernández, na ocasião, era candidata ao Senado pela província de Buenos Aires.

Eu havia me despedido de Rubén e de sua mulher no dia daquela eleição. Minha visita posterior era mais informal, eu queria cumprimentá-lo, vê-lo "no exercício de suas funções" e comentar com ele os avanços do meu trabalho. Neste novo cenário em que nos dispusemos a conversar, e envoltos na alegria do reencontro, ele me disse, sabendo de antemão que o que tinha para contar era de grande interesse para mim: "No dia 03 de outubro, tivemos um temporal fortíssimo. De manhã, choveu um pouco, e acreditávamos que salvaríamos os tetos, mas depois, de tarde, foi fortíssima a tempestade. Voou tudo pelos ares, e tivemos de visitar casa por casa... Você tinha de ter estado nesta ocasião...".

Em seguida, me mostrou um caderno no qual haviam sido registrados os dados de pessoas numeradas consecutivamente de 1 a 662. Ali se anotavam o nome, o número do documento, o domicílio e, por último, ao final de cada linha, marcava-se "sim" ou "não", segundo o caso. Olhei estupefata para o caderno diante da prolixidade com que os nomes estavam dispostos; em seguida, ele acrescentou: 
Você está vendo o "sim" e o "não": significa se votaram ou não, porque eu levo a cédula a quem visito e presto atenção se estão nos padrões. Os que dizem "não" é porque têm domicílio na capital, porque são de um puntero* que os levou para fazer o documento na capital. Mas o que acontece?... Há muitos que não gostam de mim, então, desta folha [assinalou uma tabela], eu visitei uns três ou quatro, ou então Nina ou ela [assinalando Sandra, sua secretária, que também participava da conversa]...

Passo seguinte: Sandra interrompeu e me perguntou: "Agora você entende como é?" Em poucas palavras e sem rodeios, Rubén e sua secretária me revelavam aquilo que tentei desentranhar durante o extenso período em que permaneci em Santa Rita: o modo como um dirigente peronista administrava recursos públicos, em especial planos sociais (subsídios a desempregados), chapas de metal** e alimentos, em períodos eleitorais.

O relato de Rubén era revelador acerca de diversos aspectos centrais da redistribuição de recursos na região metropolitana de Buenos Aires. As pessoas eram visitadas por vários distribuidores, que lhes ofereciam recursos a serem retribuídos com o voto. Ao mesmo tempo, aspectos imateriais como o afeto e a afinidade pessoal eram essenciais e deviam estar presentes para se encarar a visita aos vizinhos e oferecer-lhes um recurso (chapas de metal) em troca de voto.

De modo geral, as práticas exercidas nesses circuitos são rotuladas por políticos, analistas e pela imprensa como práticas ou redes "clientelistas". Em tais casos, mais do que um termo analítico, a noção de "clientelismo" torna-se uma categoria pejorativa que desqualifica essas práticas e as aproxima de "sequelas do passado". Contudo, tal apropriação recupera o termo cunhado por uma linha de interpretação de fenômenos sociais conhecidos como "patronagem" e "clientelismo". Tais conceitos referem-se a um tipo particular de relação entre pessoas que ocupam posições desiguais em termos de status, prestígio e poder, na qual há circulação e intercâmbio de bens materiais e imateriais por meio de contatos face a face entre "patrões" e seus "clientes" (Schmidt et alli 1977; Gellner et alli 1977). Entretanto, como já assinalado por Bezerra (1999:14-15), observa-se que uma parte

* [N.T.] Puntero é o termo comum para se referir aos militantes locais que trabalham para algum candidato ou linha partidária, mobilizando bases e recrutando eleitores [o equivalente, em certa medida, no Brasil, aos cabos eleitorais]. Para maiores informações, ver Quirós 2009.

** [N.T.] Material com que são feitas as casas nas chamadas villas, equivalentes às favelas brasileiras. 
da literatura consagrada ao âmbito da ciência política - que parece mais interessada nos aspectos materiais trocados entre os partícipes - deixa de lado aspectos como favores, gentilezas e gratificações. Sendo assim, os cientistas políticos tendem a ver o "clientelismo" como uma categoria que lhes permite identificar relações pessoais no interior de instituições políticas nas quais prevalece a ideia de troca de benefícios públicos por votos e apoio político (Diniz 1982; Schwartzman 1982). Nessa mesma linha de trabalho, podemos situar parte da literatura argentina que apela para o "clientelismo" para explicar aspectos diversos de um movimento nacional transformado em partido político: o peronismo. Um fenômeno que remonta a meados dos anos 1940, centrado na figura de um líder militar, Juan Perón, e com a particularidade de contar com uma data de nascimento precisa: 17 de outubro de 1945. Neste dia, uma grande mobilização social composta por trabalhadores e operários provenientes de áreas periféricas dirigiu-se ao centro da cidade de Buenos Aires para pedir a libertação de seu líder, preso dias antes na ilha Martín García. Nesse momento, Perón acumulava os cargos de secretário do Trabalho, ministro da Guerra e vice-presidente da nação, ou seja, era um homem forte de um regime realmente acossado pela oposição. Pouco depois daquele episódio, que marcaria um ponto de inflexão na história argentina, foram convocadas as eleições que transformaram Perón em presidente da nação entre 1946 e 1955 e, posteriormente, em 1973 até a sua morte, ocorrida em 1974. Seus governos caracterizaram-se por conferir centralidade à classe trabalhadora, promovendo o pleno emprego, o fomento à indústria nacional e diversas políticas como pagamento de férias, bônus de Natal, licenças-maternidade, entre outras. ${ }^{3}$ Tais políticas tiveram a peculiaridade de desencadear, por outro lado, violentos desacordos, adesões e uma rara unanimidade, a ponto de o movimento ser qualificado, em certos casos, como liderança revolucionária, experiência nacional, ditadura bonapartista e populismo autoritário (Neiburg 1998:15). Nesse sentido, quando visto da perspectiva clientelista e cinco décadas após seu nascimento, o peronismo é entendido como a forma segundo a qual "a política" se inscreve nas populações pobres, em especial da região metropolitana de Buenos Aires (os clientes), mediante redes de redistribuição de recursos diversos como planos sociais, alimentos e chapas de metal, controlados por dirigentes peronistas denominados punteros, que exigem o voto como retribuição (Auyero 2001). Nessa linha de análise, o clientelismo é o modo como o peronismo faz política junto aos pobres, transformando os três termos (clientelismo, política e peronismo) em categorias intercambiáveis. Em um trabalho posterior, o clientelismo é a lente que permite analisar a rede conformada por aqueles que compõem as diversas listas de candidatos a ocupar cargos eletivos pelo 
partido peronista durante um processo eleitoral na província de Misiones. Neste caso, os protagonistas já não são habitantes de bairros carentes, e sim "militantes", "dirigentes" e "candidatos" em cenários tipicamente proselitistas, tais como atos com oradores partidários e caravanas de candidatos (Soprano Manzo 2003). Tal objeto obrigou o autor a conferir menos atenção às pessoas convocadas para esses atos de proselitismo, assinaladas simplesmente como "a clientela" de um ou outro orador e descritas como "mulheres, crianças e alguns homens humildemente vestidos [...] aos quais era atribuída a tarefa de juntar balões, faixas e bandeiras enquanto comiam biscoitos e bebiam mate" (Soprano Manzo 2003:148). Por se tratar de textos apoiados em investigações etnográficas, tanto o trabalho de Auyero (2001) quanto o de Soprano Manzo (2003) inspiram-se em textos clássicos da antropologia, que analisaram particularmente as relações entre "patrões" e "clientes" em contextos rurais da África (Schmidt et alii 1977). Ou seja, trata-se de textos que analisam a dinâmica de relações entre pessoas situadas em posições extremas da hierarquia social, nas quais a balança do poder pendia em favor dos poderosos. Desse modo, eram retratados os laços que uniam proprietários e camponeses sem-terra ou traficantes de gado, e também membros de castas opostas, como nobres de nascimento e guerreiros ou escravos — diferenças reforçadas por aspectos culturais tais como professar línguas, religiões e dialetos diversos (Cohen 1977; Foltz 1977). Assim, era obrigação dos patrões fornecer proteção e ajuda a seus clientes, que deveriam retribuir com trabalho e esforço. Tratava-se de uma análise em que aspectos não econômicos, os favores, tinham peso central para explicar uma relação econômica por excelência: o trabalho.

Em resumo, se somarmos os elementos que compõem os esquemas do clientelismo clássico e a ciência política, obteremos como resultado a seguinte sequência: "patrão", "cliente", "trabalho", "ajuda" e "voto". No entanto, não se trata de uma simples somatória de termos equivalentes cuja ordem não alteraria o resultado ou o produto. Ao contrário, o voto, por promover a obtenção de um cargo eletivo, pode, segundo os contextos, introduzir sérias alterações nos circuitos de troca de ajudas e favores em função da dívida contraída e das possibilidades de seu cancelamento. Trata-se de um aspecto analisado meticulosamente por Heredia (1996) em relação às comunidades rurais do Brasil, nas quais a política é percebida como externa à comunidade e ligada às eleições. Para compreender a noção de externalidade da política, a autora parte daquilo que a comunidade concebe como trabalho, ${ }^{4}$ isto é, aquilo que une "patrões" e "clientes". Para os trabalhadores rurais dos engenhos açucareiros, a noção de trabalho está ligada à participação de cada um dos membros do grupo doméstico nas atividades da parcela 
familiar que circunda a casa. Nesse sentido, o trabalho no roçado é masculino, assegura Heredia, e tem caráter dominante frente a casa. É o pai de família que executa e ordena as atividades no roçado, das quais também participam a mulher e os filhos. No entanto, as atividades destes últimos não são tidas como "trabalho", e sim como "ajuda" — o mesmo termo que designa os favores que os políticos fazem em tempos de campanha, como a concessão de um emprego nos Correios, na prefeitura, ou o fornecimento de documentos, entre outros. Contudo, este sentido de "ajuda" tem, segundo a autora, outras implicações - e é aí que "o voto" ganha protagonismo, ao introduzir modificações, pois, assim como as ajudas de familiares, trata-se de ajudas que serão retribuídas, assegurando-se a continuidade da relação. As ajudas da mulher e dos filhos são retribuídas com o trabalho do chefe do grupo doméstico e, portanto, não cancelam a dívida permanente que seus membros mantêm com o responsável por seu sustento. No caso da ajuda de um político, ela tem, segundo Heredia, um significado diferente porque, apesar de o voto permitir a retribuição pelo favor recebido, ele não admite o estabelecimento de uma relação entre associados como entre iguais que trocam bens de um mesmo tipo. Nesse sentido, o voto parece ser uma moeda de troca que possibilita a passagem de um circuito de intercâmbio a outro, ou seja, do circuito de reciprocidade entre os socialmente iguais ao do "clientelismo político", no qual o "cliente" se mantém permanentemente endividado com seu "patrão" (Heredia 1996:64). Por conseguinte, o voto introduz desigualdade. Por essa razão, a comunidade também resiste a ter candidatos próprios, na medida em que chamar alguém para ser político significa convidá-lo a situar-se fora da comunidade. Isto consiste em trazer a "política", que é exterior, para dentro da comunidade, uma maneira de introduzir desigualdades entre iguais. Alguém que é eleito passa, automaticamente, a ser de fora, ou seja, deixa de ser um membro, tornando-se uma perda para a referida comunidade. O fato de que um indivíduo vote em um parente ou vizinho pode ser visto como um momento de uma relação que os une e também como uma retribuição de favores por meio do voto, mas a retribuição pelo voto significa algo mais. Afinal, quem deu seu voto a um vizinho contribuirá não somente para situá-lo em uma condição social mais alta, mas também para que o equilíbrio da relação até então mantido não seja restabelecido (Heredia 1996:68). Em resumo, o voto como um bem da rede clientelista introduz desigualdade em um mundo de iguais, um aspecto que as etnografias sobre o peronismo não conseguiram esclarecer. Tratavase de comunidades da região metropolitana e do interior do país ligadas a doadores-candidatos do peronismo, comunidades ou clientes de pessoas que ocupavam posições extremas da escala social, ou uma comunidade de 
iguais com mínimas diferenças estatutárias? Até aqui sabemos somente que a "clientela" dos candidatos peronistas é composta por "homens e mulheres humildemente vestidos". Resta-nos saber quem eram essas pessoas, como e por quem eram convocadas a participar desse evento e também como a participação nesses atos se inscrevia em seu cotidiano.

Etnografias recentes mostraram que as pessoas que participam da distribuição de recursos, seja por intermédio de doadores do partido peronista ligados ao município ou de lideranças de movimentos piqueteiros, descrevem sua aposta com uma expressão de caráter transitório. Eles se referem a "estar com fulano" ou a "estar com os piqueteiros" (Quirós 2006). Portanto, as pessoas não se reconhecem como membros da "clientela" de um "patrão", e sim vinculadas, de maneira temporária ou circunstancial, a um movimento, uma organização ou um partido político. Assim, um dos termos da relação (clientes) não se mostrava pertinente para entender o universo criado pela redistribuição de recursos na região metropolitana de Buenos Aires. Eles não eram "clientes de...", e sim "estavam com", desafiando por completo o eixo argumentativo das etnografias sobre o peronismo.

Agora, conhecendo o que ocorre com um dos agentes da relação, resta saber o que ocorria com os "patrões". Será que os distribuidores se reconheciam desse modo? Como seus vizinhos vivenciavam o fato de se tornarem candidatos? Esta candidatura introduzia, por sua vez, diferenças hierárquicas tão extremas a ponto de os candidatos encontrarem resistência por parte dos vizinhos, tal como as assinaladas a respeito das populações rurais do Brasil? E, por último, quais eram os sentidos que a política adquiria para esta comunidade? Mais precisamente, e para recuperar a sequência dos esquemas clientelistas, que sentidos ganhavam as noções de trabalho, voto e ajuda? Para responder a estas perguntas, abordarei de modo breve a trajetória de Rubén e, em seguida, identificarei seus eleitores. Em um segundo momento, tratarei do primeiro passeio que dei com ele pelo bairro, durante o qual me apresentou a alguns vizinhos. Seguirei com a convocação para um ato político, para depois comentar um percurso que realizei com Nina para inscrever as crianças de Santa Rita no restaurante popular comunitário, que começou a funcionar um mês antes das eleições daquele ano. Por último, mostrarei o ocorrido no domingo das eleições legislativas.

\section{A vida em Santa Rita}

Rubén tinha 47 anos quando o conheci, no início de 2005. É natural de Tucumán, de onde veio criança juntamente com seus pais e nove irmãos. 
Uma vez em Buenos Aires, transitaram por diversas villas da capital até que o governo os alocou em Santa Rita. Ficava para trás uma infância transcorrida nos canaviais de açúcar de sua província.

Santa Rita, ou simplesmente Santa, como a chamavam seus vizinhos, era um bairro construído sobre um terreno cedido pelo Estado, propriedade do governo da cidade de Buenos Aires, ainda que localizado no município de La Matanza. ${ }^{5}$ Teve sua origem durante o regime militar de Onganía, em 1966, e foi construído com a finalidade de abrigar "transitoriamente" as famílias desalojadas de villas da capital. Segundo seus primeiros habitantes, no início, "todas as casinhas eram iguais", ainda que daquela fisionomia restasse muito pouco, porque muitos vizinhos iam construindo um quarto a mais de acordo com as transformações familiares: um filho que se casava e trazia a mulher para a casa paterna, ou a possibilidade de se abrir um pequeno comércio na entrada da moradia. Segundo o último registro de Rubén, em 2007 ali viviam 662 famílias, que obtinham água de um tanque administrado pelo município, distintamente da luz, provinda de conexões clandestinas. Por essa razão, a empresa elétrica costumava deixá-los às escuras durante muitas horas.

Rubén vivia ali desde os momentos iniciais do bairro e morava, juntamente com Nina e seus dez filhos, em uma vivenda que compraram de uma vizinha que "deixava o bairro", localizada em frente à casa de sua sogra. Era um tanto arredio para falar sobre sua vida anterior ao ingresso "na política". Garantiu-me tão-somente que, no começo, a política consistia em "lindas reuniões com os vizinhos a quem conhecia da vida inteira", mas muitos se envolveram nas tomas e se mudaram para outros agrupamentos. Envolveram-se na ocupação de terrenos da União ${ }^{6}$ e privados que, nesse município, começou a ocorrer no início de 1986, com a finalidade de levantar morada em um bairro que respeitara as dimensões dos terrenos de 10 x 30 e, desse modo, diferenciar-se das villas, onde as casas costumam amontoar-se umas ao lado das outras. No entanto, as mudanças na vida de Rubén começariam a ser gestadas em 1989, quando Alberto Balestrini assumiu como secretário parlamentar na Câmara dos Deputados e pediu a Gabriel, amigo de Rubén, para "juntar as pessoas" de La Matanza para formar um novo agrupamento.

Segundo Rubén, naquela época, Balestrini não lhes prometeu nada. Só era preciso "suar a camisa", ou seja, convocar reuniões para "juntar vizinhos", pedir micro-ônibus, levá-los aos atos partidários e também para votar. A partir dessa convocatória, nos anos seguintes Balestrini teve uma carreira meteórica. Em 1991, foi eleito deputado federal e prometeu compensar Rubén com um cargo efetivo no Congresso. Contudo, segundo as 
palavras de nosso protagonista, "que seria eu no Congresso, e disse a ele que não; irei com você [...] a partir dali, aonde ia Balestrini eu também ia". Assim, Rubén seguiu "seu chefe" no Senado provincial entre 1995 e 1999 para logo assumir um posto permanente na folha de trabalhadores de La Matanza, momento em que Balestrini foi eleito prefeito pela primeira vez. Por essa razão, Rubén identificava-se como "um dos primeiros soldados de Alberto Balestrini porque estava com ele desde que era um humilde secretário do Congresso". Gabriel, por sua vez, pôde abandonar seu posto de contínuo no palácio a fim de situar-se como vereador peronista entre 1999 e 2003, para logo ser compensado com um cargo de secretário em um órgão do município. Era Gabriel que sempre avisava Rubén das reuniões, das noites em que deviam ser feitas as pinturas nas ruas e de qualquer outra novidade que lhe fosse comunicada por Balestrini.

Durante as eleições legislativas de 2005, foi a vez de Rubén ocupar um cargo eletivo. Foi assim que passou a integrar a lista de vereadores pela Frente da Vitória, que tinha seu chefe como candidato a deputado nacional. Naquele período, Rubén, por sua vez, administrava a totalidade dos recursos estatais que o bairro recebia. Era ele que controlava a realização de informes socioeconômicos para outorgar aos vizinhos a bolsa mensal de mercadoria proveniente do município. Também tinha a seu cargo cerca de oitenta pessoas de Santa Rita e de outros bairros vizinhos que ele inscrevera no plano Chefes de Lar, ${ }^{7}$ um subsídio para pessoas desempregadas, no início de 2002, em troca da realização de tarefas comunitárias como contrapartida.

Para a organização dessas tarefas, Rubén e Nina formaram dois grupos. Um deles era integrado em sua maioria por homens, cuja atividade consistia na limpeza de escolas, ruas e hospitais. O segundo grupo era o de "trabalhos manuais", a cargo de Nina, composto por mulheres dedicadas à elaboração de bonecos, guardanapos e outros produtos de uso doméstico destinados à comercialização. Ambos os grupos deveriam assinar diariamente sua presença nas instalações do Clube Santa Rita, localizado em frente ao bairro onde, pouco tempo antes das eleições, Rubén instalara um restaurante popular comunitário por meio de um contrato de comodato com a secretaria de Ação Social do município.

Nina vivia em Santa Rita desde os quatro anos de idade, quando chegou da província de San Juan juntamente com a família. Também acompanhava Rubén em tarefas diversas. Era ela que controlava as quarenta manzaneras ${ }^{8}$ existentes no bairro, que distribuíam leite e alimentos secos do Plano Vida para crianças menores de seis anos. Por meio de um contrato com o secretário de Ação Social de La Matanza, também estava encarregada das operações de pagamento em cheque a seis mil beneficiários do Plano Famílias. ${ }^{9}$ Este era um 
subsídio que consistia no pagamento por filho, efetuado a cada noventa dias. Por este motivo, os vizinhos costumavam chamá-lo "plano dos três meses".

Durante meus primeiros dias em Santa Rita, pedi a Rubén para conhecer o bairro e conversar com alguns vizinhos. Ele pensou um pouco e me disse: "Hummm... te interessa uma mulher com dez filhos que está bem ferrada?" Deixei que ele escolhesse as pessoas, e me disse: "Vamos até o fundo, na casa de Josefina..." Uma vez ali, Rubén me apresentou a ela e lhe pediu que conversasse um pouco comigo sobre "o bairro" e essas coisas. Imediatamente, ela me fez entrar e pediu desculpas pela desordem da casa. Sentamo-nos à mesa, em que ainda estavam os pratos do almoço de seus filhos menores.

Josefina tinha 35 anos naquela ocasião. Era casada e tinha 11 filhos. Um deles havia falecido cerca de um ano antes por causa de problemas respiratórios, e já tinha um neto. Naquele dia, sete dos dez filhos de Josefina me olhavam atônitos enquanto eu conversava com sua mãe em torno da mesa de jantar. Nesse espaço, contou-me que era empregada doméstica e que seu marido estava sem trabalho, mas às vezes fazia changas* na construção. Contou também que Rubén o inscrevera no Plano Chefes de Lar porque ela havia pedido, "porque não falharia com ele". Pouco tempo depois da inscrição, Rubén "lhe avisou que tinha saído para fazer pagamentos" e assim iniciou as tarefas de limpeza em uma escola de Puerta del Sol, uma villa distante cerca de setecentos metros de Santa Rita. Josefina sentia apreço e respeito por Rubén, a quem chamava de "Don Rubén". Referiu-se a ele desse modo para me contar que, certo dia, lhe pediu "por favor" que a mandassem para a escola 47, que ficava na entrada de Santa Rita mais próxima à sua casa, e Rubén, que "sempre me ajuda", acatou seu pedido.

Como vemos, Josefina não pertencia ao grupo de trabalhos manuais e sim ao de limpeza em dependências públicas. Como Rubén comentou comigo mais tarde, ela era "das poucas que trabalhavam" porque, nessa escola, permitiam que levasse parte dos alimentos preparados para o almoço, e assim assegurava o jantar dos filhos. Por sua vez, Josefina recebia mensalmente a mercadoria do município e o leite do Plano Vida para dois de seus filhos, que lhe eram repassados por uma manzanera da mesma tira que a sua - termo que designa os estreitos corredores em que se localizam as moradias.

Naquela tarde, antes que eu fosse embora, mostrou-me a máquina de lavar roupa que havia comprado "de segunda mão" no dia em que recebeu o plano, pela qual pagou cinquenta pesos, já que com os cem restantes pagou o armazém no qual comprava fiado. Segundo Josefina, o dinheiro do

* [N.T.] Trabalhos temporários. 
Plano "durava apenas um minuto". Despedi-me e, amavelmente, ela saiu para me acompanhar em direção à casa de Rubén, mas cruzamos com ele a poucos metros dali. Mal me viu, começamos a voltar na direção da sua casa, mas se deteve como alguém que se recorda de algo repentinamente e me disse, enquanto começava a retroceder: "Não, venha por aqui, vamos na [casa] de Eugenia."

A casa de Eugenia estava localizada a pouquíssimos metros da de Josefina, no mesmo corredor. Rubén me havia advertido antes de entrar que, poucos meses antes, um de seus filhos havia sido assassinado por um bando de moleques "do fundo" e que a visita seria rápida porque, "quando se lembra do filho morto, desata a chorar". Quando chegamos, Rubén bateu palmas e logo surgiu Eugenia para atendê-lo, uma mulher de cerca de 45 anos, morena e com cabelo comprido. Rapidamente, ele lhe explicou a que se devia minha presença e, em seguida, ela me fez entrar.

Quando ficamos a sós na cozinha de sua casa, ela me convidou a sentar à mesa e esquentou água para que tomássemos mate. Eugenia era viúva e recebia uma pensão de seu falecido marido. Tinha quatro filhos, dois dos quais estavam presos e duas moças que ainda viviam com ela; o quinto filho era falecido. Quando começou a falar sobre ele, seu tom de voz mudou completamente e, imediatamente, seus olhos se encheram de lágrimas. Em seguida, disse: "Todas as vezes que tenho de ir para lá, para 'o fundo', vejo com meus próprios olhos os assassinos do meu filho e, cada vez que me veem, baixam a cabeça os sem-vergonha!" Enquanto secava as lágrimas, dizia-me: "Além disso, quando ele morreu, eu não tinha onde o velar. Graças a Deus, Rubén me emprestou o clube para que eu pudesse velá-lo ali, porque a minha família é muito grande e eu não poderia velá-lo em minha casa."

O relato de Eugenia me comovia muito, e eu não sabia como consolá-la, enquanto ela continuava dizendo algo resignada: "Eu sempre quis ir embora de Santa... mas aqui estou." Diante de tanta dor, a única coisa que me ocorreu perguntar a ela era se tinha amigas em Santa Rita ou a quem recorrer quando se sentia só e abatida. Lentamente, um tímido sorriso esboçou-se em seu rosto, como se a minha pergunta lhe permitisse descobrir que, apesar do momento difícil que atravessava, tinha alguém em quem podia confiar, e me disse aliviada: "Sim, sim... Tenho... aqui em frente", e assinalou a casa de sua janela. "Fernanda... quer ir lá?" "Sim", respondi-lhe sem hesitar. Antes de deixarmos sua casa, fez um comentário que antecipava o que ocorreria minutos mais tarde, na casa de Fernanda, quando me disse: "Bom, olha, como o Rubén anda metido em política, há muitas pessoas que não gostam dele por aqui, mas... vamos?", perguntou e em seguida saímos da sua casa e cruzamos o corredor. A casa de Fernanda era contígua à de Josefina. 
Ao chegarmos, Eugenia chamou da porta, e surgiu Fernanda, uma mulher loura de cabelo curto, baixa estatura e bem gordinha que, em seguida, nos fez entrar. Mal havíamos entrado e Eugenia me apresentou como uma moça fazendo estudos em Santa Rita para uma universidade do Brasil. Lembro-me da surpresa ao me deparar, logo ao entrar na sala, com uma cadeira de rodas, que pertencia a Juan, o filho mais novo, de 11 anos. Fernanda tinha 31 anos, era viúva e, além do filho inválido, que havia sido operado recentemente, tinha uma filha adolescente que ainda cursava o Ensino Médio.

Mal havíamos entrado em sua casa e ela foi logo nos oferecendo mate. Apresentou-me sua mãe, que estava com ela, e ligou a televisão. Começou a mudar de canal até que apareceu na tela a imagem de Luís D'elia, presidente da Federação de Terras e Vivendas, a organização piqueteira mais importante do município. Fernanda disse então: "Hummm... deixo aqui porque estive andando com eles." Dirigindo-se a mim, acrescentou: "Porque antes eu era piqueteira."10

Fiquei atônita com a identificação de Fernanda porque ela foi a primeira pessoa que encontrei que se reconhecia como tal desde que eu começara a frequentar La Matanza, o município de Buenos Aires no qual ocorreram os primeiros piquetes da região metropolitana e os de maior duração. A identificação de Fernanda despertou vivamente minha curiosidade, e comecei a interrogá-la, ansiosamente, acerca de como tinha se envolvido com os piqueteiros, em um bairro onde a maioria dos recursos parecia ser controlada por pessoas estreitamente ligadas ao município e à cúpula do partido peronista. O relato de Fernanda continha importantes precisões em relação aos planos, à organização dos piquetes e também à trajetória de Rubén. Estas foram as suas palavras quando a interroguei acerca de seu contato com os piqueteiros: "Por volta de 97, 98, comecei a andar com os 'jalecos amarelos' porque um amigo da minha mãe tinha dito que, pelo fato de eu ser viúva e ter um filho doente, devia encarar uma luta popular, ir aos piquetes e lutar por um plano."

A expressão "jalecos amarelos" devia-se à vestimenta usada pelos beneficiários dos planos Trabalhar e Bonairense, lançados em 1996 para a realização das tarefas de limpeza e enxágue de ruas e, por essa razão, havia se transformado em um tipo de ícone ou marca visível para se ter acesso a um plano. Com essa referência, Fernanda manifestava certa antiguidade na participação em piquetes e em modalidades de ingresso em planos de emprego. "Devia ir" aos piquetes e "lutar" por um plano; foi assim que, após ter participado de vários bloqueios a rodovias, obteve seu Plano Trabalhar, em primeiro lugar, e Chefes, em seguida, graças a Miguel, sua liderança. 
Entre as suas primeiras atividades nos piquetes estava a do controle de comparecimento das pessoas que iam "trabalhar na construção" e também às assembleias no bairro El Ingenio, no qual os piquetes eram decididos. Para "ajudar" sua liderança, com o antecedente de sua atividade na construção, envolveu-se, certa vez, no controle da frequência durante os dias em que ocorreram os bloqueios às rodovias. Ela mesma confeccionava as listas de presença, em quadros de dupla entrada, colocando o nome das pessoas nas linhas e os dias da semana nas colunas, de maneira tal que era possível identificar os dias em que as pessoas estiveram presentes ou se ausentaram do piquete. Fernanda entregava essa listagem à sua liderança, convertendo-se em um importante instrumento para a atribuição de novos planos.

Contudo, ela própria, como relatou naquela tarde, impunha suas sanções "porque nos piquetes são feitos acampamentos com lonas e fogueiras; se queimam cobertas, e é preciso limpar; por isso... se alguma pessoa ia embora antes, depois, quando voltava, eu a fazia varrer toda a rodovia..." Fernanda continuava assim seu relato:

Nos piquetes, se passa fome, se passa frio; eu dormia nessas cadeiras de plástico [assinalou as cadeiras que estavam empilhadas em uma lateral da mesa de jantar] que eu levava e me cobria com cobertas... Além disso, comíamos o que pedíamos nos armazéns, que já nos odiavam e... também, naquela época, quase não ficava com meus filhos... os deixava com a minha mãe.

Para Fernanda, a frequência aos piquetes foi a forma sacrificada de obter seu plano, e o controle da presença, provavelmente, a forma de obter um espaço no interior da organização. Ela mesma assegurava, um tanto resignada, que esta última tarefa a obrigava a ser "um pouco os ouvidos das liderenças", ou seja, a delatar o comportamento de seus companheiros, mas que aceitou fazê-lo mesmo assim. Fernanda também me contou, naquela tarde, que havia alguns anos que sua liderança falecera e que ela própria se encarregara de ir ao Ministério do Trabalho a fim de levar "os papéis" para que não lhe tirassem o plano.

Depois de responder extensamente a todas as minhas perguntas, foi ela que me interrogou, quando repentinamente disse: "Você, como chegou a Santa Rita?" Em seguida, Eugenia respondeu por mim: "Foi Rubén que me apresentou a ela." Fernanda respondeu, completamente desiludida: "Uhhh..." Esclareci que o que havíamos conversado ficaria entre nós, que Rubén não sabia que eu tinha falado com ela. Depois, quando soube da minha rede de relações no bairro, atrevi-me a apresentar a ela outro de meus informantes, quando lhe perguntei: "Por que, estando aqui em Santa, 
você participou dos piquetes para obter um plano e não se inscreveu com o Rubén?" A isso respondeu, com um sorriso que deixava ver em seu rosto uma expressão de desprezo: "Porque naquele tempo Rubén não tinha nada... carregava botijões [de gás]." A resposta de Fernanda testemunhava com maiores detalhes a atividade anterior de Rubén, que ele odiava recordar e sobre a qual Fernanda forneceu dados temporais: ela travara contato com os piqueteiros em 97/ 98, "quando Rubén não tinha nada".

Desse modo, por intermédio de Fernanda, soube que durante muitos anos Rubén teve de alternar "a política" com outras atividades, como a venda de botijões de gás, e que sua dedicação plena deu-se, muito provavelmente, a partir de 1999, quando Balestrini foi eleito prefeito de La Matanza, nomeando-o trabalhador permanente do município.

\section{O comparecimento a um ato político}

O Clube Santa Rita é um grande galpão de alvenaria com teto de chapa metálica, localizado na entrada do bairro e em cuja parte externa há uma pequena quadra de futebol para que as crianças da vizinhança possam jogar. Funcionava como sede da junta vicinal presidida por Rubén; ali era "El Tucu" que cuidava das instalações.

El Tucu era um homem de sessenta anos e da maior confiança de nosso protagonista. A seus cuidados estavam, em primeiro lugar, as ferramentas e a apreciada caminhonete azul de Rubén, como também as duas listas, da "limpeza" e de "trabalhos manuais", nas quais os beneficiários do Plano Chefes de Lar assinavam presença. Em certa manhã do mês de julho de 2005, a cada uma das pessoas que ingressavam no clube para assinar seu comparecimento, dizia: "Na sexta-feira, venha às 10 horas; há um ato. Venham aqui por perto, que Kirchner estará presente." A cada um dizia mais ou menos o mesmo.

Rubén permaneceu no clube durante toda aquela manhã, mas não participava da convocação. Circulava, fazendo-se de desentendido, cuidando de sua caminhonete. Em uma oportunidade na qual Tucu abandonou a entrada do clube para dirigir-se aos fundos a fim de renovar a água do mate, o próprio Rubén, debaixo de seu veículo, o advertiu de que havia outra pessoa na entrada e que era preciso anunciar a novidade, ao invocá-lo imperativamente: "Tuuuuuuuucuuuu!"

No dia do ato, desde muito cedo dois micro-ônibus ficaram estacionados na porta do clube; lentamente começaram a chegar os convocados. Rubén e Nina iam e vinham do clube à sua casa, localizada a escassos cem metros, 
para avisar a filha mais velha dos cuidados que deveria tomar durante a ausência de ambos. Como de costume, era Tucu quem advertia sobre como aplicar o controle de presença nesse dia em particular, dizendo: "Eles vão assinar dentro do ônibus, porque senão fazem como das outras vezes: vêm, assinam e voltam correndo para casa." Entre os presentes estava Sandra, que me foi apresentada por Nina como a futura encarregada do restaurante comunitário. Algumas mulheres aproximaram-se de Nina para lhe explicar pessoalmente o motivo pelo qual não podiam participar do ato, e ela respondia: "Não se preocupe, venha na segunda-feira para assinar." Os homens mantiveram-se à parte, contando piadas, até que Sandra se dirigiu a Nina e lhe disse: "Teu marido disse que estamos indo." Havia dois micro-ônibus: um para os homens e outro para as mulheres. Era Rubén que indicava o trajeto aos motoristas, ordenando algumas paradas para esperar microônibus de outros agrupamentos. Desse modo, também podia alternar entre um e outro veículo durante a viagem. O comparecimento ao ato foi maciço. Havia somente dois oradores: Balestrini, que fazia as vezes de anfitrião, e o presidente Kirchner. Antes de empreender a viagem de volta, Nina perguntou às mulheres se não queriam ir saudar Cristina. Todas aceitaram com prazer o convite e, em seguida, fizemos o longo percurso até encontrarmos o micro-ônibus que nos levaria de volta a Santa Rita. Quando o encontramos, Nina contou o número de mulheres, ainda que nesta viagem também houvesse alguns homens, e pediu que assinassem sua presença em uma folha que lhes entregou. Subimos no veículo, e teve início nosso regresso. Saímos em direção à rodovia, e Rubén, já mais calmo, sentou-se no meio do micro-ônibus. Pouco a pouco, as pessoas se aproximaram para conversar com ele. Parecia tratar-se de uma modalidade implícita, uma regra do jogo conhecida por todos: o comparecimento ao ato era o momento para se aproximar e conversar pessoalmente com Rubén. Foram vários os que se aproximaram. No momento em que chegamos ao clube, uma senhora idosa que conversara com Nina durante a viagem permaneceu timidamente ao lado de Rubén até que Nina a advertiu de que não podia deixar passar o momento, ao insistir: "Peça a ele, agora!"

Naquela tarde, despedi-me de Nina e Rubén e segui meu caminho até o ponto de ônibus que me levaria de volta a Buenos Aires. No trajeto, encontrei Josefina, a primeira vizinha que me fora apresentada por Rubén, que chegou correndo e um tanto agitada. Surpreendeu-se ao ver-me e me perguntou ansiosa se eu tinha comparecido ao ato e quantas pessoas haviam ido. Respondi que somando os dois micro-ônibus devia haver cerca de vinte pessoas, ao que Josefina replicou: "Isso não é nada; com toda a gente que Don Rubén tem anotada..." Em seguida, comentou, preocupada: "Será que 
Don Rubén ficou chateado comigo?" Continuou explicando: "Ocorre que hoje estavam dando pílulas anticoncepcionais de um plano em uma saída distante; e eu já tenho dez e não quero mais e, bom, não cheguei... vou falar com Don Rubén", finalizou Josefina.

\section{A abertura do restaurante comunitário}

Cerca de um mês após o ato, nos primeiros dias de setembro, Nina dispôs todo o necessário à abertura do restaurante comunitário que funcionaria nas instalações do clube. Pediu a Tucu que marcasse uma reunião com as mulheres de trabalhos manuais, pendurou alguns cartazes indicativos nas paredes que assinalavam as modalidades de inscrição: "Para se inscrever no restaurante comunitário, dirija-se à delegação municipal munido dos documentos dos seus filhos". Havia outro que dizia: "Somente se autoriza a entrega de alimentos em casos de extrema necessidade, doença com atestado médico, inválidos e dificuldades de transporte de idosos." Nina foi insistente na convocação. Quando cruzava no bairro com algumas das mulheres, dizia imperativamente: "Vocês têm de ir trabalhar no restaurante comunitário, senão não irão receber." Sua insistência categórica provavelmente devia-se à necessidade de cobrir todos os postos: a preparação dos alimentos, os cuidados com as crianças e anciãos e as tarefas de limpeza. Também havia outro motivo: devido a algumas ocupações que Nina mantinha junto à Secretaria de Ação Social, como a organização do pagamento de planos a beneficiários do Plano Famílias, o grupo estivera inativo; era preciso, portanto, tirá-las da inércia na qual estavam desde esse período de inatividade.

Para o anúncio da abertura e a inscrição das crianças, Nina dispôs de várias opções além dos cartazes no clube. Pôs um anúncio na FM do bairro, mas não abandonou a modalidade que frequentemente utilizava com $\mathrm{Ru}$ bén: a visita casa por casa. Numa dessas manhãs em que estava com ela e Sandra, acompanhei-as em seu percurso. Sandra fez seu próprio trajeto, e eu segui Nina, atravessando os corredores do bairro. Nossa primeira visita foi a uma casa localizada a uns setenta metros da de Nina e Rubén. Havia uma menina na porta que cuidava de três meninos menores, e Nina lhe perguntou: "Você quer inscrever as crianças no restaurante comunitário?" "Sim", repondeu a menina, "mas não têm documento; são da minha irmã, que está presa", sentenciou por último. "Bom, eu coloco que os documentos estão sendo expedidos", disse-lhe Nina. "O domicílio daqui, qual é?" A menina, em seguida, respondeu: "Ahh... não sei. Faz pouco tempo que estou aqui." "Bom, vou colocar que é o corredor 30 e, na semana que vem, 
pode mandá-los" — foram as últimas palavras de Nina. Saímos dali e fomos a outras casas. Nina visitava pontualmente casas localizadas em diferentes pontos do bairro. Logo empreendemos o caminho em direção ao fundo e fomos à casa de Josefina.

Uma vez ali, Nina bateu palmas, e Josefina saiu para nos atender e fazer entrar. Nenhuma das duas fez menção ao ato de Kirchner ocorrido cerca de um mês antes. Nina se limitou a lhe pedir os documentos de seus filhos para inscrevê-los no restaurante comunitário, e Josefina lhe respondeu um tanto preocupada: "Não tenho nada, só o meu. Perdi os dos dez [filhos] quando fui fazer um trâmite na capital." "Bom", disse-lhe Nina, "vou ver se não pode emiti-los pela Ação Social, que te deem pelo menos os dos menores, que não fique sem os documentos deles; agora, ponho que estão em trâmite." Josefina agradeceu a Nina, e fomos embora.

Ao sair, passamos pela porta da casa contígua, onde vivia Fernanda com seus dois filhos, mas Nina não se deteve ali. Seguiu ao largo até a casa da outra vizinha, localizada mais perto da rua principal. Chamou minha atenção que Nina não tivesse inscrito o filho de Fernanda, que era inválido. Recordemos que, no dia em que a visitei pela primeira vez com Eugenia, a primeira coisa com a qual me deparei ao entrar foi a cadeira de rodas de seu pequeno Juan. Minha surpresa devia-se ao fato de que, pouco tempo antes de iniciarmos o percurso, Nina havia colado um cartaz no clube indicando que os inválidos estavam autorizados a retirar alimentos para levar para casa. Uma modalidade que parecia formulada como um privilégio (somente se autoriza a entrega de alimentos a inválidos e pessoas idosas...), ou seja, como uma singularidade concedida a poucos. Por conseguinte, a ausência de convocação a Fernanda era sinal de desentendimento ou inimizade, algo que a fazia não ser chamada para receber um recurso, mesmo que cumprisse os requisitos que a normativa da Secretaria de Ação Social do município impunha aos vizinhos para poderem se candidatar. E vice-versa: eram convocadas pessoas que não preenchiam os requisitos formais e também aquelas que não tinham cumprido a obrigação de comparecer ao ato.

\section{O dia das eleições}

No domingo das eleições legislativas de outubro de 2005, o cenário foi transferido para a Unidade Básica de Santa Rita, localizada na entrada do bairro, na rua em que transitavam as principais linhas de ônibus que por ali passavam. Naquele dia, vi ali reunidas todas as pessoas que conheci durante os longos meses de minha permanência no bairro. Ali estavam as "moças 
dos trabalhos manuais", os homens da limpeza, os meninos que ajudavam Rubén nos grafites noturnos. Sandra não estava na Unidade Básica porque naquele dia atuava como fiscal de mesa em uma escola próxima. Havia um clima festivo, quase de comunhão, e também de tensão. Alguns chegavam dizendo: "Na escola 47 não há cédulas... olho, que lá está a contra!", advertia Chávez, antigo companheiro de política de Rubén.

Nina, junto a duas de suas filhas, avisava todos os que se aproximavam acerca da escola na qual deveriam votar, ajudada por um computador no qual havia salvado os padrões eleitorais. Simultaneamente, controlava os micro-ônibus que levavam os vizinhos às respectivas escolas. Cuidava, especialmente, para que permanecessem até as 15 horas, como tinham combinado os motoristas com seu marido. Rubén, por sua vez, circulava em um carro conduzido por um de seus genros, verificando a provisão de cédulas em diversas escolas aldeãs. Parecia cansado e emocionado. Sua jornada havia começado pouco depois das 3 horas da madrugada para ultimar todos os preparativos. Não era para menos, estava em jogo um evento que marcaria um passo a mais em sua vida política: passaria a ocupar um cargo legislativo como compensação por mais de duas décadas de trabalho junto a Alberto Balestrini.

Pouco depois das 15 horas, Josefina chegou à Unidade Básica de mãos dadas com suas duas filhas menores. Surpreendeu-me seu semblante, um tanto cansado e adormecido; parecia ter acabado de se levantar. Aproximouse de Nina para lhe perguntar o local de votação, e esta última, um tanto aborrecida, respondeu: "Mas, Josefina, os ônibus eram até as 3 da tarde..." Josefina então perguntou, algo desconcertada: "Sim, mas a eleição não é até as 6 horas?" "Sim", respondeu Nina, "mas só temos os micro-ônibus até as 3 horas, senão terão de ir de ônibus". "Ahh...", disse Josefina, toda preocupada, "mas não tenho grana para a passagem".

Nina não lhe deu mais atenção, seguiu atendendo novos vizinhos que chegavam, e pediu a um dos rapazes que levasse em sua caminhonete o último grupo para votar, porque correspondia a uma escola localizada a mais de vinte minutos de viagem de Santa Rita.

\section{As visitas: o caráter personalizado da redistribuição}

Uma mulher com dez filhos e uma mãe cujo filho havia sido assassinado à queima-roupa foram as vizinhas que Rubén escolheu para me apresentar. Eu, uma pessoa de fora interessada em conhecer o bairro onde ele residia há mais de quatro décadas. A modalidade que usou para tanto foi a que 
costumava utilizar na hora de distribuir os recursos que controlava: a visita casa por casa. A visita era uma prática recorrente entre os militantes do partido peronista para convencer os votantes da lista que deviam votar (Rosato 2003:75).

Contudo, as visitas que realizei com ele tornaram-se reveladoras não somente do conhecimento e da relação que ele mantinha com seus vizinhos, mas também das propriedades sociais daquela comunidade. Os habitantes de Santa Rita compunham uma comunidade de pessoas desempregadas ou com empregos informais, como o trabalho doméstico, a venda ambulante e a indústria de construção.

Tal comunidade dependia, em grande medida, para sua reprodução dos recursos que o Estado lhe propiciava por intermédio de Rubén. Nesse contexto, a noção de trabalho estava vinculada ao cumprimento das tarefas comunitárias exigidas pelas normativas dos planos e ao comparecimento aos atos políticos. A mesma noção também se aplicava às tarefas próprias dos militantes: convocar para os atos, organizar a provisão de transporte, controlar registros e visitar votantes. Sem descontar os empregos formais que os militantes obtinham, em muitos casos, após anos ou mesmo décadas de militância, as tarefas eram também definidas com a mesma categoria e referidas em termos de identidade. Assim, quem ocupava um posto na folha estabelecida de trabalhadores do município passava a "ser municipal".

Essa era a trajetória de Rubén, Gabriel, seu compadre, e de Sandra, secretária de Rubén quando este assumiu como vereador. No entanto, nenhum deles tinha se tornado externo à comunidade. Rubén continuava residindo em Santa Rita e realizando as mesmas tarefas que exercia antes de se tornar candidato: visitas casa por casa oferecendo recursos.

Portanto, "a política" não era uma atividade externa, estando antes ligada à provisão de bens do Estado que os vizinhos recebiam para seu sustento, por intermédio de Rubén. Em outras palavras, as noções de trabalho e política eram extremamente aparentadas, a ponto de, em certas circunstâncias, converterem-se em sinônimos. Ambas aludiam também às próprias tarefas de redistribuição de recursos. No entanto, como vimos, para os vizinhos era bastante difícil cumprir os requisitos formais, como a apresentação de documentos e a comprovação de domicílio. Por essa razão, sem os favores e as ajudas dos distribuidores, o funcionamento do circuito se via altamente fragilizado, pois os vizinhos corriam o risco de perder a continuidade como beneficiários de recursos públicos, o que também afetava Rubén, que via ameaçado o número de votantes com que contava para a eleição em que saía candidato. Nessas situações, os "favores" permitiam manter os vizinhos como partícipes ativos da rede de redistribuição. Essa intervenção 
criava uma dívida que podia ser retribuída com o voto, mas aqui não havia alteração ou passagem de um circuito de reciprocidade entre iguais ao do "clientelismo político" entre "patrões" e "clientes", antes o contrário. O fato de que um vizinho fosse eleito era vivido por algumas pessoas como uma festa. Para outros podia ser um fato indiferente, mas não era uma situação à qual se opunham.

Estava claro que, ao ser eleito vereador, Rubén tinha mais poder, ou seja, contava com mais recursos para redistribuir e, por essa razão, passava a ocupar uma posição hierárquica, mas não deixava de ser um vizinho de Santa Rita, habitando a mesma casa e realizando as mesmas tarefas anteriores ao momento em que se tornou candidato.

\section{Conclusões}

A relação entre trabalho e política parece ser a chave para identificar os membros dos circuitos de redistribuição de bens públicos nos quais o voto se constituía como moeda principal de troca. No caso de Santa Rita, uma comunidade de pessoas desempregadas que dependiam de recursos estatais para sua reprodução, as noções de trabalho e política eram estreitamente aparentadas. Como vimos, os habitantes desse pequeno bairro de Buenos Aires alternavam períodos de desemprego com atividades informais no serviço doméstico, na venda ambulante ou na indústria de construção. Tal situação afetava tanto simples vizinhos quanto o distribuidor principal de recursos e candidato pelo partido peronista. Por essa razão, as noções de "patrões" e "clientes" não se mostravam pertinentes para analisar o universo da redistribuição na periferia urbana de Buenos Aires. O que ganhava relevância ao seguirmos as trajetórias dos que aderiam a essa bandeira era a possibilidade de reconhecermos profundas transformações no mundo do trabalho.

Rubén havia chegado a Buenos Aires, proveniente de Tucumán, em 1966, momento em que o governo militar da época eliminou subsídios e cotas aos pequenos canavieiros e fechou o engenho de açúcar em que seu pai trabalhava. Sua escolarização era bastante precária; passou por diversas ocupações informais, como a venda de botijões de gás, até que seu "ingresso na política", na década de 90, lhe permitiu após uma década de militância o acesso a um emprego formal na folha de trabalhadores do município e, em seguida, transformar-se ele próprio em candidato. Uma trajetória similar à daqueles que protagonizaram a façanha do dia 17 de outubro de 1945: migrantes do interior rural recém-chegados à metrópole urbana e transformados em uma nova classe operária. Mais precisamente, em trabalhadores 
formais sindicalizados que, amparados no direito da greve geral, saíram às ruas para pedir a libertação de seu líder. No entanto, a formalização de Rubén como trabalhador não se deu na área industrial, como ocorria no auge das décadas de 40 e 50, e sim no setor estatal, quase meio século mais tarde, em pleno apogeu das políticas neoliberais e como prêmio por seu esforço e lealdade a Balestrini - uma situação da qual se beneficiavam uns poucos em um contexto no qual o desemprego parecia ser a regra. Assim, Rubén investia-se de certa hierarquia em relação a seus vizinhos, a quem concedia recursos e que convocava para atos peronistas. Ainda assim, não perdia sua condição de vizinho: continuava sendo "Rubén" ou "Don Rubén", só que agora "andava metido em política". Ao mesmo tempo, é imperioso chamar a atenção para o fato de que, apesar das transformações na política do emprego, o peronismo continuava sendo um movimento que os setores populares reconheciam como interlocutor. Agora, entretanto, não competia com outros partidos políticos, e sim com organizações de desempregados que tinham a mesma tarefa de redistribuir recursos e convocar os vizinhos para atos e piquetes. Nesse sentido, novas categorias devem ser pensadas para interpretar um movimento tão complexo, que começou como referência para os novos operários provenientes do interior e, meio século mais tarde, continuou convocando, desta vez massas de desempregados. Como vimos, a extrapolação das noções de "patronagem" e "clientelismo" não nos ajuda a compreender um universo de vizinhos que faziam frente ao desemprego, ao delito e à pobreza, envolvendo-se em circuitos de recursos que os uniam a um partido ou a uma organização social. O caso de Santa Rita forneceu-nos elementos não somente para compreender que se tratava de um universo de iguais, mas também para reconhecer as novas configurações que adquire a noção de trabalho em um contexto a priori definido como "desocupação". Isto, por sua vez, constituiu-se como berço de um novo líder: ao trafegar pela rota da militância e da candidatura eleitoral e, por meio desta, da "vida política", Rubén ainda mantinha o equilíbrio das relações até então estabelecidas com seus vizinhos.

Recebido em 20 de maio de 2009

Aprovado em 30 de janeiro de 2010

Tradução de Roberta Ceva

Laura Colabella é doutora em antropologia social pelo PPGAS/ Museu Nacional/ UFRJ. E-mail: <mlauracol@yahoo.com.ar> 


\section{Notas}

* Este artigo desenvolve alguns pontos de minha tese de doutorado defendida no PPGAS/ Museu Nacional/ UFRJ, em 9 de março de 2009, sob orientação da professora Lygia Sigaud (in memoriam), que foi minha principal interlocutora nas diversas instâncias de análise e argumentação das evidências que aqui apresento. Agradeço também a Federico Neiburg, João Pacheco de Oliveira, Rosana Guber, Patrícia Vargas, Fortunato Mallimaci e ao(à) avaliador(a) anônimo(a) da Revista Mana, que com seus comentários e críticas me permitiu dar continuidade e novos rumos à minha pesquisa.

${ }^{1}$ Para preservar os que me confiaram sua palavra, alterei os nomes próprios das pessoas e lugares. Somente mantive aqueles que correspondem a pessoas públicas; também conservei o nome do município onde realizei a pesquisa.

${ }^{2}$ Villa é o termo pejorativo com o qual são designadas, na Argentina, as localidades não delimitadas como terrenos, povoadas por vivendas precárias e nas quais o acesso aos serviços de água e luz é obtido por meio de conexões clandestinas.

${ }^{3}$ A literatura que aborda o fenômeno do peronismo é exaustiva. Para mencionar somente os mais destacados: Germani (1973); Murmis \& Portantiero (1984); James (1990); Neiburg $(1995,1998) ;$ Plotkin $(1995,2007)$.

${ }^{4}$ Em um trabalho anterior, a mesma autora analisou particularmente a organização do trabalho familiar dos pequenos produtores do Nordeste do Brasil. Ver Heredia 1979.

${ }^{5}$ O município de La Matanza, com $320 \mathrm{~km}^{2}$, mais de um milhão e meio de habitantes e trinta por cento da população com necessidades básicas não satisfeitas, é o distrito mais extenso e pobre da região metropolitana de Buenos Aires. Desde a abertura democrática, ocorrida em 1983, até a atualidade é governado pelo partido peronista. No começo dos anos 1990, suas rodovias converteram-se em cenários de mobilizações e piquetes organizados por líderes territoriais de villas e assentamentos que demandavam ao governo o controle dos planos e alimentos. Dessa maneira, os movimentos piqueteiros transformaram-se, para os vizinhos, numa outra via para a obtenção de recursos do Estado, em disputa com a via dos agentes municipais.

${ }^{6}$ Em meados da década de 1980 multiplicaram-se, em diversos municípios da região metropolitana de Buenos Aires, ocupações de terrenos da União e privados por parte de numerosas famílias, com a intenção de ali estabelecerem suas casas e erigirem um bairro com espaços comuns, como posto de primeiros socorros e quadra de futebol, por exemplo. Trata-se de um fenômeno voluntário, ao qual as pessoas se referiam por meio da expressão "ir ou entrar na toma", e no qual eram rigorosamente respeitados os limites dos terrenos, o que muitas vezes originava conflitos, em alguns casos resolvidos mediante o emprego de armas de fogo. Ao mesmo tempo, tal exigên- 
cia contribuía para que esses "bairros" se diferenciassem das villas, onde as casas se amontoavam e eram menos frequentes as possibilidades de urbanização. Para uma análise detalhada das ocupações no município de La Matanza, ver Merklen 1991.

${ }^{7}$ O Plano Chefes de Lar era um subsídio a desempregados no valor de 150 pesos mensais, lançado pelo governo interino de Eduardo Duhalde, logo após uma intensa mobilização desencadeada por saques a importantes cadeias de supermercados, em dezembro de 2001. O mesmo exigia aos postulantes atribuir a responsabilidade sobre os filhos menores ao governo. Aqueles que tinham acesso ao benefício eram obrigados a realizar tarefas comunitárias como contrapartida.

${ }^{8}$ Manzaneras eram as mulheres que distribuíam leite e mercadoria do Plano Vida. Seu nome devia-se a uma divisão própria ao espaço urbano, a manzana, espaço em que se localiza um conjunto de vivendas. Assim, a manzanera distribuía os alimentos às crianças que residiam perto de sua casa. Para uma etnografia desse Plano e o perfil dessas mulheres, pode-se consultar Masson 2004.

${ }^{9} \mathrm{O}$ montante do benefício era calculado de acordo com o número de membros da casa. Para o primeiro, eram pagos 100 pesos, e 25 para cada um dos demais, até o máximo de cinco pessoas. Os beneficiados não eram obrigados a realizar qualquer tarefa como contrapartida, mas deviam provar o comparecimento dos filhos à escola e à administração das vacinas de acordo com o plano nacional.

${ }^{10}$ A etnografia de Quirós (2006), ao desviar o objeto da análise dos "movimentos piqueteiros" para os indivíduos que deles participam, mostrou como as pessoas definem essa participação de maneira diferenciada. Alguns afirmam "ser piqueteiros", enquanto outros se referem à sua aposta com uma frase que marca o caráter transitório da mesma, ao sustentarem "estar com os piqueteiros".

\section{Referências bibliográficas}

AUYERO, Javier. 2001. La política de los pobres. Las prácticas clientelares del peronismo. Buenos Aires: Editorial Manantial.

BEZERRA, Marcos O. 1999. Em nome das bases: política, favor e dependência pessoal. Rio de Janeiro: Editorial Relume Dumará.

COHEN, Abner. 1977. "The social organization of credit in a west cattle market". In: S. W. Schmidt et alii (orgs.), Friends, followers and factions. A reader in political clientelism. Berkeley: University of California Press. pp. 233-241.

DINIZ, Eli. 1982. Voto e máquina política. Patronagem e clientelismo no Rio de Janeiro. Rio de Janeiro: Paz e Terra. FOLTZ, William. 1977. "Social structure and political behavior of senegalese 
elites". In: S. W. Schmidt et alii (orgs.), Friends, followers and factions. A reader in political clientelism. Berkeley: University of California Press. pp. 242-249.

GELLNER, Ernest \& Waterbury (orgs.). 1977. Patrons and clients in Mediterranean socities. London: Duckworth.

GERMANI, Gino. 1973. "El surgimiento del peronismo: el rol de los obreros y de los migrantes internos". Revista Desarrollo Económico, 13(51):435-488.

HEREDIA, Beatriz. 1979. A morada da vida: trabalho familiar de pequenos produtores do Nordeste do Brasil. Rio de Janeiro: Editora Paz e Terra.

. 1996. "Política, família, comunidade". In: M. Palmeira, M. Goldman (orgs.), Antropologia. Voto e representação política. Rio de Janeiro: Editora Contra Capa. pp. 57-71.

JAMES, Daniel. 1990. Resistencia e integración. El peronismo y la clase obrera argentina, 1946-1976. Buenos Aires: Editorial Sudamericana.

MASSON, Laura. 2004. La política en femenino. Género y poder en la provincia de Buenos Aires. Buenos Aires: Editorial Antropofagia-IDES.

MERKLEN, Denis. 1991. Asentamientos de La Matanza. La terquedad de lo nuestro. Buenos Aires: Editorial Catálogos.

MURMIS, Miguel; PORTANTIERO, Juan C. 1984. Estudios sobre los orígenes del peronismo. Buenos Aires: Editorial Siglo XXI.

NEIBURG, Federico. 1995. "El 17 de Octubre de 1945: un análisis del mito de origen del peronismo". In: J. C. Torre (org.), El 17 de Octubre de 1945. Buenos Aires: Editorial Ariel. pp. 219-283. . 1998. Los intelectuales y la invención del peronismo. Buenos Aires: Editorial Alianza.
PLOTKIN, Mariano. 1995. "Rituales políticos, imágenes y carisma: la celebración del 17 de Octubre y el imaginario peronista (1945-1951)". In: J. C. Torre (org.), El 17 de Octubre de 1945. Buenos Aires: Editorial Ariel. pp. 171-217. . 2007. El día que se inventó el peronismo. La construcción del 17 de Octubre. Buenos Aires: Editorial Sudamericana.

QUIRÓS, Julieta. 2006. Cruzando la Sarmiento. Una etnografía sobre piqueteros en la trama social del sur del Gran Buenos Aires. Buenos Aires: Editorial Antropofagia-IDES. . 2009. "Política e economia na ação coletiva: uma crítica etnográfica às premissas dicotômicas". Mana. Estudos de Antropología Social, 15(1):127-153.

ROSATO, Ana. 2003. "Líderes y candidatos: las elecciones 'internas' en un partido político". In: A. Rosato; F. Balbi (orgs.), Representaciones sociales y procesos políticos. Estudios desde la antropología política. Buenos Aires: Editorial Antropofagia. pp. 61-79.

SCHMIDT, S. W. et alii (orgs.). 1977. Friends, followers and factions. A reader in political clientelism. Berkeley: University of California Press.

SCHWARTZMAN, Simón. 1982. Bases do autoritarismo brasileiro. $2^{\mathrm{a}}$ ed. Rio de Janeiro: Editora Campus.

SOPRANO MANZO, Germán. 2003. Formas de organización y socialización en un partido político. Etnografía sobre facciones, alianzas y clientelismo en el peronismo durante una campaña electoral (Año 1999, ciudad de Posadas, Misiones, Argentina). Tese de doutorado, PPAS/Universidad Nacional de Misiones. 


\section{Resumo}

Este artigo enfoca o modo como um candidato a vereador pelo partido peronista exercia a distribuição de recursos públicos (planos sociais e alimentos) no município de La Matanza, a oeste da Grande Buenos Aires, durante a campanha legislativa de 2005. A primeira parte apresenta a trajetória do candidato e de alguns dos vizinhos que dele dependiam. A segunda parte examina o modo como o protagonista convocava a um ato político e os sentidos das condutas dos atores na sucessão de eventos - entre os quais se contavam a abertura de um restaurante comunitário e o dia das eleições. Identificam-se também as coerções exercidas sobre eles e as implicações em relação ao cumprimento ou descumprimento das obrigações recíprocas. A análise permite uma melhor compreensão da dinâmica e da complexidade dos processos que regem extensos circuitos de redistribuição nos quais os recursos do Estado são concedidos em troca de votos na periferia urbana da Grande Buenos Aires.

Palavras-chave Clientelismo, Política, Puntero, Vizinho, Visita, La Matanza.

\section{Abstract}

This article focuses on the ways in which a candidate running for city councillor and representing the Peronist party organized the distribution of public resources (social plans and food programs) in $\mathrm{La}$ Matanza, a district in the west of Greater Buenos Aires, during the 2005 election campaign. The first part describes the personal trajectory of the candidate and some of the neighbours dependent on him. The second part examines how this leading figure rallied election campaigners and the meaning invested in their behaviours during a series of events - including the opening of a 'soup kitchen' and the election day itself. The text also identifies the constraints imposed on these actors and the implications associated with their compliance (or failure to comply) with mutual obligations. This analysis enables a clearer understanding of the dynamics and complexity of the processes regulating vast political circuits in which State resources are redistributed in exchange for votes on the outskirts of Greater Buenos Aires.

Key words Clientelism, Politics, Campaigners, Neighbours, Visit, La Matanza. 